\title{
Expression of Semaphorin4C by Th2-stimulated B cells
}

\author{
Jean-Philippe Drolet ${ }^{1,2^{*}}$, Julie Guay ${ }^{1}$, Yasaman Nouhi ${ }^{1}$, Bruce Mazer ${ }^{1,2}$ \\ From Canadian Society of Allergy and Clinical Immunology Annual Scientific Meeting 2010 \\ Victoria, Canada. 3-6 November 2010
}

\section{Background}

Semaphorins are a family of proteins implicated in neurogenesis, angiogenesis and axonal migration. Previous work from our laboratory has shown that Th2stimulated B cells express a unique semaphorin, SEMA4C. Given the roles of other semaphorins, we hypothesized that SEMA4C was expressed on Th2stimulated B cells and might play a role in B cell trafficking and tissue homing therefore being expressed stronger in terminally differentiated B cells, such as memory and plasma cells.

\section{Experiment and results}

$B$ cells were purified from tonsils removed from children undergoing routine tonsillectomy. They were cultured for 24 hours or 7 days at a concentration of $5 \times 10^{4}$ cells $/ \mathrm{mL}$ in complete medium in the presence of $\alpha \mathrm{CD} 40$ with either IFN $\gamma$, IL-4, IL-21 or both IL-4 and IL-21. RNA was extracted, cDNA was made, and SEMA4C mRNA was amplified by qPCR and compared to the housekeeping gene GAPDH. After 24h culture, SEMA4C mRNA expression was detected only in IL-4stimulated cells but after 7 days, the expression was much stronger in both conditions containing IL-21, and decreased in IL-4-only stimulated cells.

B cells were also similarly cultured for 72 hours at a concentration of $0.5 \times 10^{6}$ cells $/ \mathrm{mL}$ in chamber slides. Slides were stained for SEMA4C with a fluorescent Alexa488 antibody and then visualized using fluorescent microscopy. As expected, stimulation with IL-21 yielded

* Correspondence: jean-philippe.drolet@mail.mcgill.ca

'Meakins-Christie Laboratories, McGill University, Montreal, H2X 2P2, Canada

Full list of author information is available at the end of the article much higher SEMA4C expression than IL-4 alone whereas IFN $\gamma$ did not induce significant staining. Figures 1 and 2.

\section{Conclusion}

SEMA4C is induced in B cells upon Th2 stimulation but increases further upon follicle-like differentiation triggered by IL-21. This data confirms that SEMA4C is specific to terminally-differentiated B cells and supports our hypothesis that it might play a role in B-cell trafficking and homing in peripheral tissue follicles. SEMA4C could therefore be a key player in local allergic inflammation.

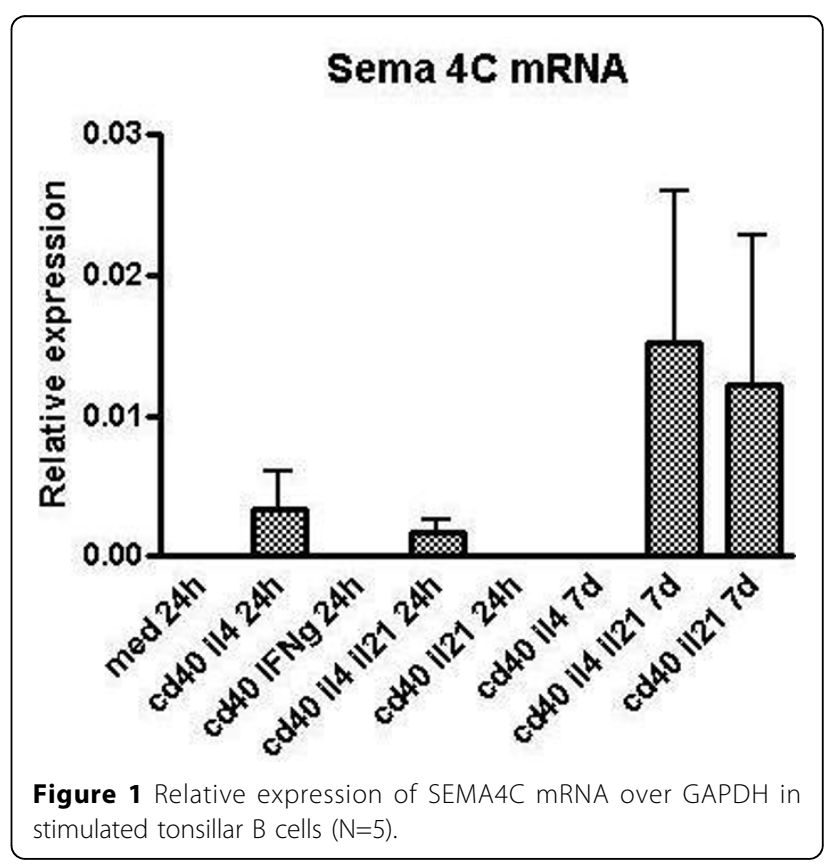



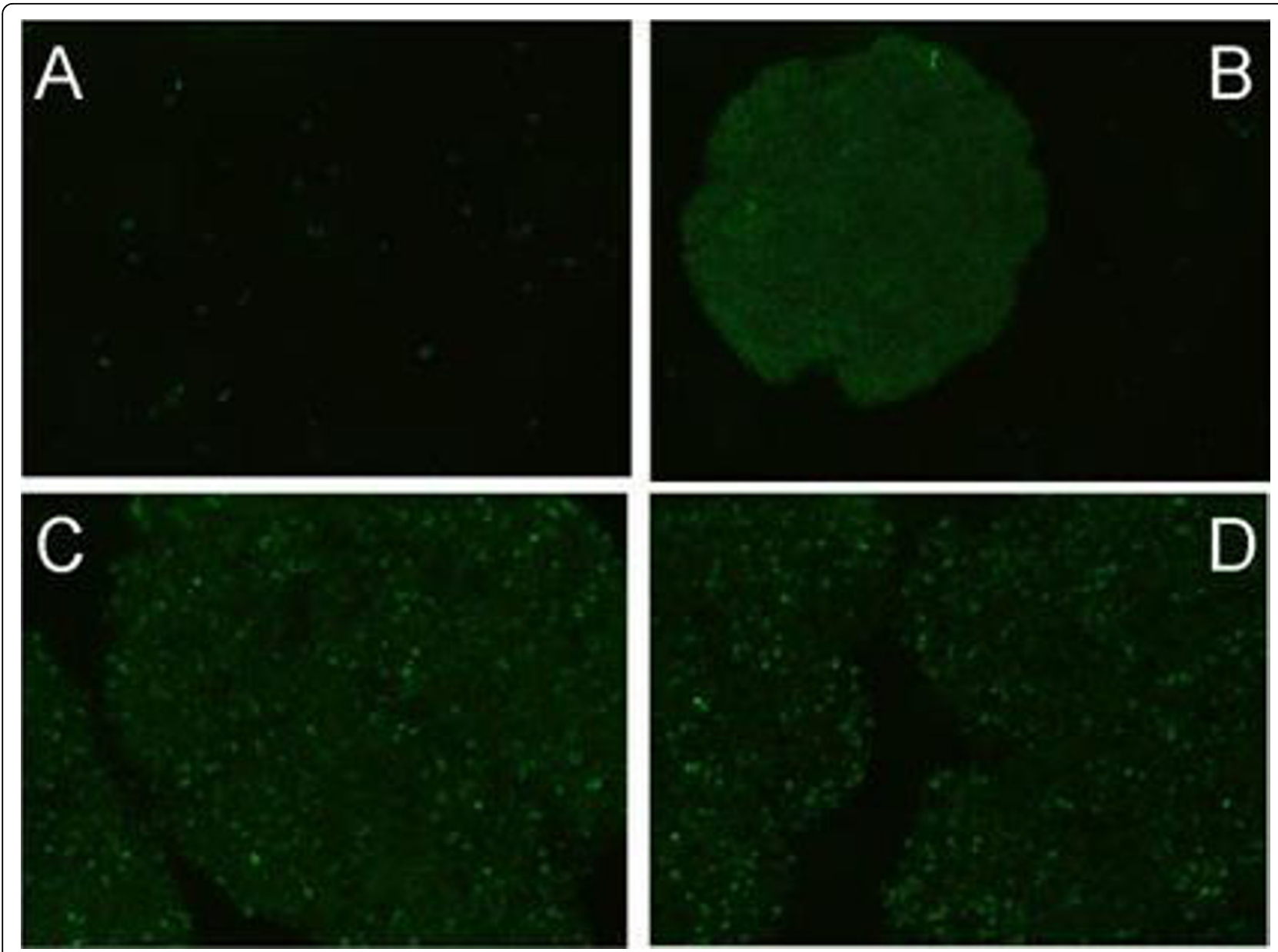

Figure 2 Immunofluorescent staining at 10X magnification for SEMA4C in B cell cultures is associated with "follicle-like" clones. Stimulations: A) $\alpha \mathrm{CD} 40+\mathrm{IFN} \gamma, \mathrm{B}) \alpha \mathrm{CD} 40+\mathrm{IL}-4$, C) $\alpha \mathrm{CD} 40+\mathrm{IL}-4+\mathrm{IL}-21, \mathrm{D}) \alpha \mathrm{CD} 40+\mathrm{IL}-21$.

Author details

${ }^{1}$ Meakins-Christie Laboratories, McGill University, Montreal, H2X 2P2, Canada. ${ }^{2}$ Division of Pediatric allergy and clinical immunology, McGill University Health Center, Montreal, Quebec, Canada, H3H 1P3.

Published: 4 November 2010

\section{doi:10.1186/1710-1492-6-S2-P23}

Cite this article as: Drolet et al:: Expression of Semaphorin4C by Th2-

stimulated B cells. Allergy, Asthma \& Clinical Immunology 2010 6(Suppl 2): P23.

\section{Submit your next manuscript to BioMed Central} and take full advantage of:

- Convenient online submission

- Thorough peer review

- No space constraints or color figure charges

- Immediate publication on acceptance

- Inclusion in PubMed, CAS, Scopus and Google Scholar

- Research which is freely available for redistribution

Submit your manuscript at www.biomedcentral.com/submit 